\title{
Evaluating the annual nature of juvenile rings in Bolivian tropical rainforest trees
}

\author{
Claudia C. Soliz-Gamboa • Danaë M. A. Rozendaal • \\ Gregório Ceccantini - Veronica Angyalossy • \\ Klaas van der Borg • Pieter A. Zuidema
}

Received: 30 October 2009/Revised: 9 June 2010/ Accepted: 8 July 2010/Published online: 25 July 2010

(C) The Author(s) 2010. This article is published with open access at Springerlink.com

\begin{abstract}
Knowledge on juvenile tree growth is crucial to understand how trees reach the canopy in tropical forests. However, long-term data on juvenile tree growth are usually unavailable. Annual tree rings provide growth information for the entire life of trees and their analysis has become more popular in tropical forest regions over the past decades. Nonetheless, tree ring studies mainly deal with adult rings as the annual character of juvenile rings has been questioned. We evaluated whether juvenile tree rings can be used for three Bolivian rainforest species. First, we characterized the rings of juvenile and adult trees anatomically. We then evaluated the annual nature of tree rings by a combination of
\end{abstract}

Communicated by A. Bräuning.

Contribution to the special issue "Tropical Dendroecology".

Electronic supplementary material The online version of this article (doi:10.1007/s00468-010-0468-z) contains supplementary material, which is available to authorized users.

C. C. Soliz-Gamboa $(\bowtie)$ · D. M. A. Rozendaal · P. A. Zuidema Section of Ecology and Biodiversity, Institute of Environmental Biology, Faculty of Science, Utrecht University,

P.O. Box 80084, 3508 TB Utrecht, The Netherlands

e-mail: sol_clau@yahoo.com

C. C. Soliz-Gamboa · D. M. A. Rozendaal

Programa de Manejo de Bosques de la Amazonía Boliviana (PROMAB), Universidad Autónoma de Beni (UAB),

P.O. Box 107, Riberalta, Bolivia

G. Ceccantini - V. Angyalossy

Instituto de Biociências, Universidade de São Paulo,

Rua do Matão, 277, São Paulo, SP 05508-090, Brazil

K. van der Borg

Department of Physics and Astronomy, Faculty of Science,

Utrecht University, P.O. Box 80084, 3508 TB Utrecht,

The Netherlands three indirect methods: evaluation of synchronous growth patterns in the tree- ring series, ${ }^{14} \mathrm{C}$ bomb peak dating and correlations with rainfall. Our results indicate that rings of juvenile and adult trees are defined by similar ring-boundary elements. We built juvenile tree-ring chronologies and verified the ring age of several samples using ${ }^{14} \mathrm{C}$ bomb peak dating. We found that ring width was correlated with rainfall in all species, but in different ways. In all, the chronology, rainfall correlations and ${ }^{14} \mathrm{C}$ dating suggest that rings in our study species are formed annually.

Keywords Juvenile tree-rings · Adult tree-rings .

Tropical forest - Dendrochronology .

${ }^{14} \mathrm{C}$ bomb peak dating $\cdot$ Rainfall correlations

\section{Introduction}

The juvenile stage is crucial in the life cycle of tropical forest trees. In this phase, trees grow from the dark forest understory to the forest canopy, a process that lasts several decades to a century (Lieberman and Lieberman 1987; MartínezRamos and Alvarez-Buylla 1998; Worbes and Junk 1999; Vieira et al. 2005). Knowing which factors govern juvenile growth is important to understand how trees successfully reach the canopy (Brienen and Zuidema 2006a) and for designing forest management systems (Brienen and Zuidema 2006b). Notwithstanding the importance of information on juvenile tree growth, long-term data are hardly available, as most permanent research plots exist for less than 20 years (Peacock et al. 2007). Tree-ring analysis offers the possibility to reconstruct the full growth history of a tree, including its juvenile phase, and thus provides the essential information to evaluate juvenile growth strategies (Worbes 1999, 2002; Brienen et al. 2006; Rozendaal et al. 2010). 
Over the past decade, the number of ring analysis studies of tropical trees has increased (Worbes 2002; Brienen and Zuidema 2005; Schongart et al. 2006). In tropical forests with a distinct dry season, clear tree rings can be recognized anatomically, and these are often annual (Worbes 1999; Alves and Angyalossy-Alfonso 2000). Most tree-ring studies have considered only adult rings, discarding the innermost juvenile rings of adult trees, or the recently produced rings of extant juvenile trees. Juvenile rings were not used as their annual nature is often questioned (Dünisch et al. 2003; Brienen and Zuidema 2005). Three reasons to doubt the annual character of juvenile rings have been suggested: (1) diameter growth of juvenile trees may be limited by light availability rather than seasonally low water availability, as is the case for adult trees (Sass et al. 1995). During periods of deep shade, cambial dormancy may be induced in these trees, resulting in rings that are unrelated to seasonality (Fritts 1976; Carlquist 2001). (2) The anatomical ring definition of juvenile trees may differ from that of adult trees of the same species (Fukazawa 1984; Worbes 1999; Carlquist 2001). Also, juvenile rings of slow-growing individuals often exhibit a high frequency of wedging rings (Sass et al. 1995). (3) The high number of rings counted on some juvenile trees makes their annual nature suspicious if one takes into account that most tropical forests are rather dynamic (Baker et al. 2005).

Thus, in order to apply ring analysis to evaluate growth patterns of juvenile tropical trees, clarity should be obtained about the recognition and the annual character of juvenile rings. In natural forest stands, directly checking the annual nature of rings by ring counting in trees of known age (Worbes 1995) is usually impossible. There are several alternatives to evaluate periodicity in juvenile growth in an indirect way. First, a commonly used and successful method is to search for synchronous growth patterns across trees-ring series, and use these to develop a chronology. The chronology describes the common fluctuations of standardized ring width values of a group of trees (Stahle 1999; Worbes 1999; Brienen and Zuidema 2005; Schongart et al. 2006). Finding such common growth fluctuations over time is an indication that rings are likely to be formed annually. Another method is to correlate the tree-ring chronology with instrumental climate data (rainfall, temperature). Significant correlations with climatic variables provide very strong support that rings are formed annually (Worbes 1999; Brienen and Zuidema 2005; Schongart et al. 2006). If a chronology cannot be built, or correlations with climatic variables are not found, there is still a third way to evaluate the periodicity of ring formations by using the ${ }^{14} \mathrm{C}$ bomb peak dating (Worbes and Junk 1989; Vieira et al. 2005). The nuclear experiments of the late $1950 \mathrm{~s}$ and $1960 \mathrm{~s}$ raised the levels of ${ }^{14} \mathrm{C}$ in the atmosphere (Hua and Barbetti 2004). These atmospheric
${ }^{14} \mathrm{C}$ values were compiled by several researchers and, nowadays, a calibrated curve of the excess of ${ }^{14} \mathrm{C}$ [p.mil] $\left(\mathrm{D}^{14} \mathrm{C}\right)$ allows a confident dating based on the isotope ${ }^{14} \mathrm{C}$ levels after 1955 (Hua and Barbetti 2004). This method is especially useful for dating rings of juvenile trees of which the inner rings were formed after 1955.

In this study, we aimed to evaluate the annual nature of juvenile tree-rings for three Bolivian rainforest species. To this purpose, we first, described the juvenile ring structures anatomically and compared these with adult rings. We then used a combination of methods (evaluation of synchronous growth patterns in the tree-ring series, ${ }^{14} \mathrm{C}$ bomb peak dating and correlations with rainfall) to evaluate the annual character of juvenile rings. We end by discussing the suitability of these methods.

\section{Study area and species}

The study area is located in the northern part of Bolivia, Department of Pando. The climate in the region is seasonal, with a distinct dry season from May to September with precipitation below $100 \mathrm{~mm}$ per month. The mean total precipitation is $1,690 \mathrm{~mm}$ and the mean temperature is $27^{\circ} \mathrm{C}$ (Riberalta, $11^{\circ} 00^{\prime} \mathrm{S} 66^{\circ} 07^{\prime} \mathrm{W}$, averages for 1943-2007 and 1951-2004, respectively). The study was carried out at the logging concession "Los Indios" $\left(10^{\circ} 26^{\prime} \mathrm{S}, 65^{\circ} 33^{\prime} \mathrm{W}\right)$ located at $86 \mathrm{~km}$ from the town of Riberalta. The forest at the study site is semi-deciduous forest with a dense canopy at 30-35 $\mathrm{m}$ and some emergent trees up to $45 \mathrm{~m}$. The understory is composed of trees of 15-25 $\mathrm{m}$ and a shrub level of variable density of 1-6 m height (Navarro and Maldonado 2006).

We studied three canopy tree species Clarisia racemosa Ruiz \& Pavón (Moraceae), Peltogyne cf. heterophylla M.F.Silva (Fabaceae) and Cedrelinga catenaeformis Ducke (Fabaceae), (further referred to by genus name). The study species differ in shade tolerance but none of them is a pioneer (sensu Swaine and Whitmore 1988) (see Table 1 for more details). Two of the species have been used for adult tree-ring research in the past (Brienen and Zuidema, 2005, 2006a, b; Brienen et al. 2006), but definitions for juvenile rings have not been established.

\section{Data collection}

From April to July 2007 we collected 45-48 stem disc samples per species from trees of $1-$ to $35-\mathrm{cm}$-diameter at breast height (dbh) (Table 1). Using a chainsaw, the samples of Clarisia were collected at $50 \mathrm{~cm}$ height and Peltogyne and Cedrelinga were collected at $1 \mathrm{~m}$. Additionally, we collected three wood pieces of $20 \mathrm{~cm}^{2}$ per species, from 
Table 1 Characteristic of the studied species

\begin{tabular}{|c|c|c|c|c|c|c|}
\hline \multirow[t]{2}{*}{ Species } & \multirow[t]{2}{*}{ Family } & \multirow[t]{2}{*}{ Ecological group } & \multicolumn{2}{|c|}{ Leaf fall behaviour } & \multicolumn{2}{|c|}{ Collected samples } \\
\hline & & & Juvenile & Adult & No. & dbh range $\mathrm{d}^{\mathrm{d}}$ \\
\hline Clarisia racemosa Ruiz and Pavón & Moraceae & Shade tolerant ${ }^{\mathrm{a}}$ & Evergreen $^{c}$ & Evergreen $^{\mathrm{a}}$ & 45 & $1-30$ \\
\hline Peltogyne cf. heterophylla M.F. Silva & Fabaceae & Shade tolerant ${ }^{\mathrm{b}}$ & Evergreen $^{c}$ & Brevi-deciduous $^{b}$ & 48 & $1-30$ \\
\hline Cedrelinga catenaeformis Ducke & Fabaceae & Long-lived pioneer ${ }^{\mathrm{a}}$ & Evergreen $^{c}$ & Brevi-deciduous $^{\mathrm{a}}$ & 46 & $1-35$ \\
\hline
\end{tabular}

${ }^{a}$ (Mostacedo et al. 2003)

b (Pinard et al. 1999)

c Personal observations

${ }^{\mathrm{d}}$ dbh measured in centimetres at $1.30 \mathrm{~m}$ height

large felled trees, which were used for characterization of adult rings. All samples were air-dried and polished using grits up to 1,000 . In order to improve the quality of the grinding, Clarisia and Peltogyne were polished in a constant flow of water.

We then selected a subsample of five stem discs per species, based on ring visibility and estimated dates of the rings between 2 and $10 \mathrm{~cm}$ dbh in the period 1959-1980, this, to improve the accuracy of the ${ }^{14} \mathrm{C}$ dating method. Each disc was cut cross-sectionally in order to obtain two disc copies. On each copy the same main radius of $2 \mathrm{~cm}-$ width was marked. As main radius we selected the longer radius or the radius that had best visibility of the rings. One of the copies was used to take sections for anatomical treering characterization while the other was prepared for treering analysis and ${ }^{14} \mathrm{C}$ dating.

\section{Anatomical tree-ring characterization}

Pieces of wood of $2 \mathrm{~cm}^{3}$ from the juvenile discs were obtained in a radial sequence from bark to pith. At the same time, a piece of $2 \mathrm{~cm}^{3}$ was obtained from each adult tree. The wood pieces of Clarisia and Peltogyne were softened by boiling in water for more than $120 \mathrm{~h}$ while Cedrelinga was boiled for approximately $20 \mathrm{~h}$. Then, we obtained transversal sections, of 20 - to $40-\mu \mathrm{m}$-thickness, with a sliding microtome. After dehydrating we stained the sections using safranin 1\% and astra blue 1\% (Gerlach 1984). The sections were then fixed on permanent slides for microscopy observations. We also examined the polished samples using a stereomicroscope. The anatomical characteristics that define the ring boundaries were photographed under the stereomicroscope and microscope.

\section{Tree-ring series and synchronous growth}

The tree-rings were identified on all 45-48 samples of juvenile trees using a $40 \times$ magnification stereomicroscope.
To detect ring structures, we used anatomical markers of ring boundaries, characterized from the transversal sections. We pinpoint the rings in the main radius and in at least two other radii per tree. The samples were dated following the Schulman convention (1956) by which the calendar year assigned to the ring correspond to the year in which growth begins. We visually cross-dated the radii within the trees following every tenth ring along the disc, correcting, in this way, for locally absent and false rings. Rings widths were measured along the radii at $0.01 \mathrm{~mm}$ precision using a LinTab 5 measurement device and TSAPWin software.

The quality of the cross-dating within and between trees was verified using the software COFECHA (Holmes 1983). A mean stand chronology per species was developed using cross-dated trees that showed a synchronous growth pattern. Each tree-ring series was first detrended using the Hugershoff growth curve provided by ARSTAN, this in order to remove the size-dependent growth variation. Then each tree was standardized and then averaged with the others (Cook 1985; Cook and Kairiukstis 1990). Standardization was performed using the windows version of ARSTAN (Cook and Kairiukstis 1990; Cook and Holmes 1996). ARSTAN generates standard chronologies by combining standardized tree-ring series with bi-weight robust estimation (Cook and Holmes 1996). We used a 20-year window with an overlap of 10 years between adjacent windows to determine the mean correlation coefficients (Rbar; Briffa 1995).

\section{${ }^{14} \mathrm{C}$ dating}

${ }^{14} \mathrm{C}$ bomb peak dating was applied to five samples per species. We collected samples of at least $50 \mathrm{mg}$ of wood from three tree-rings supposedly formed in the period 1969-1981. The samples were taken between 2 and $5 \mathrm{~cm}$ from the pith. An extra sample was collected from four trees (two for Clarisia and two for Peltogyne) in the period $1957-1959$ closer to the pith in order to verify the annual 
character of the earlier rings. The $\mathrm{D}^{14} \mathrm{C}$ [p.mil] determination was done in the holocellulose portion of the samples, at the Van de Graaff Laboratory at Utrecht University, according to their protocol for Accelerator Mass Spectrometry analysis (van der Borg et al. 1987).

We determined the date for the obtained positive $\mathrm{D}^{14} \mathrm{C}$ values using the program CALIbomb (http://intcal.qub.ac. uk/CALIBomb) with the data set compiled for the southern hemisphere (SH1) (Hua and Barbetti 2004). For each sample, we summed all probabilities of the possible ages up to $\approx 95 \%$ (2-sigma errors; $P<0.05$ ) and assigned the most likely date based on all samples belonging to one tree.

\section{Rainfall correlations}

We evaluated the presence of correlation between the standard chronologies and the rainfall data using the monthly precipitation record for Riberalta for 1943-2000. Significant correlations of the chronology with rainfall were checked for the current growing season (Sep-Apr, $T-0), 1$ year $(T-1)$ and 2 years before $(T-2)$ the year of ring formation. In this study, annual precipitation was considered as the sum of the monthly precipitation from September to August. The record for Riberalta was provided by SENAMHI (Servicio Nacional de Meteorologia e Hidrologia, Bolivia). For Cedrelinga we used a shorter period (1957-2006), as juvenile trees were rather young. We calculated Pearson correlations in SPSS v.16.0

\section{Results}

Anatomical tree-ring characterization

All three species presented diffuse porous rings at both adult and juvenile stages (Figs. 1, 2, 3). We did not find indications that ring structures differ across life stages for our study species. However, there were differences in the visibility of the ring-boundaries between juvenile and adult trees.

In Clarisia, juvenile growth ring boundaries were not clearly distinguishable. There is a band (two to four cells wide) of marginal parenchyma cells (Fig. 1), normally followed by a fibrous zone (Fig. 1a, b, d). In the juvenile phase, the marginal parenchyma can be both at the end or the beginning of the fibrous zone. Confluent parenchyma forming bands can obscure the ring-boundary identification when it overlaps with the marginal parenchyma in both juvenile and adult trees. In adult trees, however, rings are identified with less difficulty, as the marginal parenchyma is not very often overlapping with confluent parenchyma forming bands (Fig. 1b, d).
Peltogyne presented clear ring boundaries (Fig. 2). Marginal parenchyma and small-diameter vessels can be used as ring boundary markers. Also, the degree of confluence of vasicentric and aliform parenchyma is important to distinguish the boundaries (Fig. 2b, d). In juvenile wood, the tree-ring identification presents some difficulties due to the existence of deposits in the vessels and axial parenchyma, which produces a general darkening of the wood (Fig. 2b). These darker regions are caused by fibrous zones, regions where there are smaller amounts of parenchyma and vessels (Fig. 2b). In addition, rings closer to pith can be discontinuous and wedging rings are common (Fig. 2c). We therefore advise that boundary structures that are visible in at least $25 \%$ of the discs are considered as ring boundaries. We found resin/mucilage canals in juvenile and adult trees, but these are not strictly associated with ring limits (Fig. 2d).

The ring boundaries of Cedrelinga trees are not easily distinguishable in both juvenile and adult stages (Fig. 3). Fibre cells of the late wood become thick-walled and radially flattened (Fig. 3c, d). These boundary markers are not always evident as seen in Fig. $3 \mathrm{~b}$, and may become more dubious in periods of slow growth in adult trees. False rings are common, formed by discontinuous thickwalled and radially flattened fibre cells (Fig. 3c, d). Thus, without adequate training ring identification in the adult and juvenile stage may be cumbersome.

\section{Tree-ring series}

Results from COFECHA indicated high inter-series correlation within trees for all the species (Table 2). A group of trees with synchronous growth pattern was identified for each species, leading to a successful chronology development (Fig. 4; Table 2). The chronology for Clarisia included $29 \%$ of the all sampled trees, and this was $27 \%$ for Peltogyne and $26 \%$ for Cedrelinga. All chronologies included at least two of the five trees used for ${ }^{14} \mathrm{C}$ dating. In the case of Cedrelinga, we used the ${ }^{14} \mathrm{C}$ dating to correct ring definitions in three samples before building the chronology. The Rbar of the chronologies was $0.25,0.27$ and 0.21 for Clarisia, Peltogyne and Cedrelinga, respectively, which verifies the presence of synchrony. The trees used to build the chronologies had variable diameter and age (Fig. 5).

\section{${ }^{14} \mathrm{C}$ dating}

${ }^{14} \mathrm{C}$ bomb peak dating was conducted in order to verify the annual nature of the juvenile tree-rings. Figure 6 shows the relation of sampled ring date obtained from ring counts and that determined by ${ }^{14} \mathrm{C}$ dating. The ring dates were verified (with a 95\% confidence level) for two discs (trees) of 
Fig. 1 Clarisia racemosa. Transversal sections. a, c Juvenile tree, b, $\mathbf{d}$ Adult tree. Growth ring markers characterized by a band of marginal parenchyma (arrows). Fibrous zones indicated by asterisks $(*)$
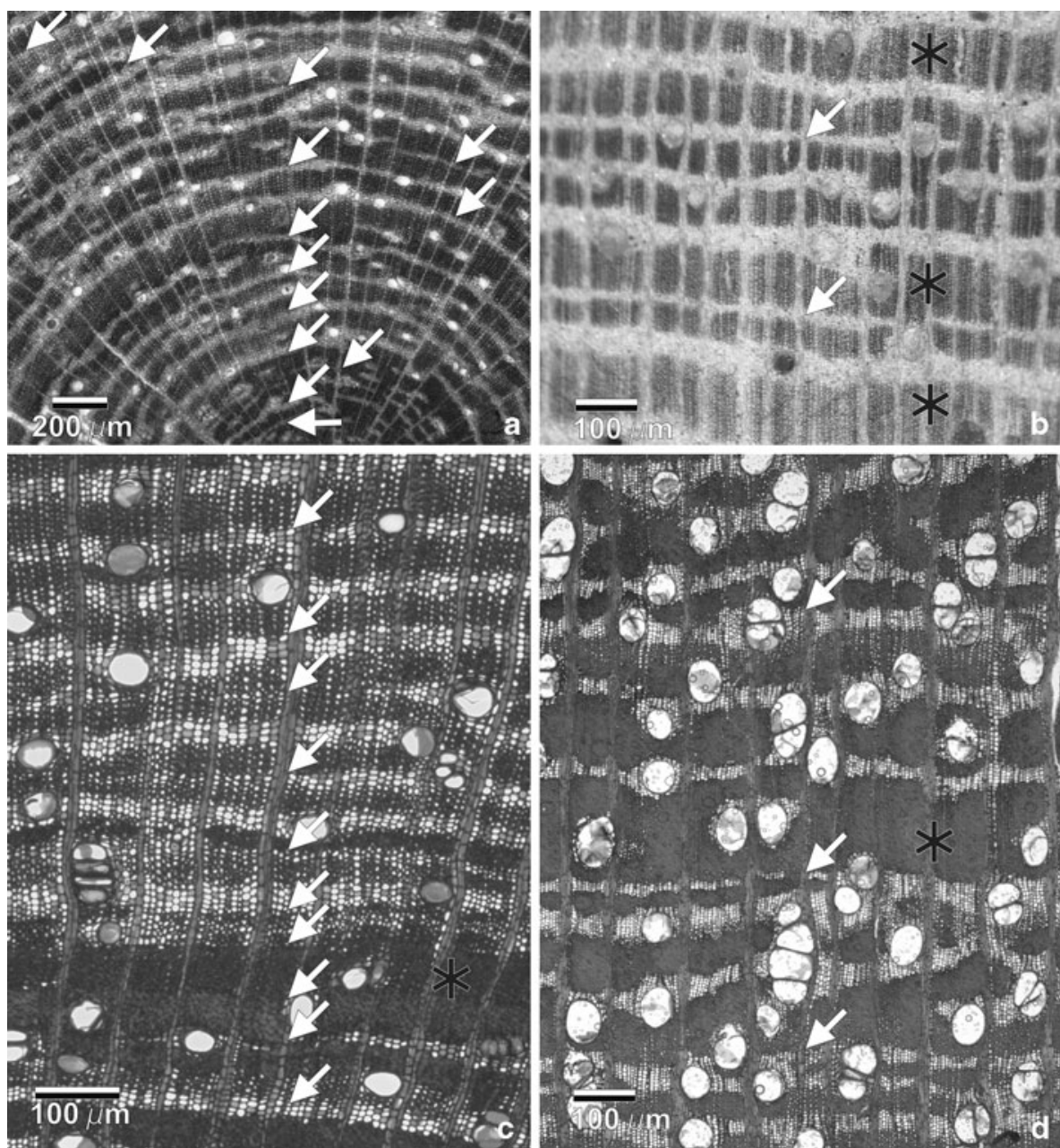

Clarisia and three discs of Peltogyne, with an error of \pm 1 year. These trees had been already included in the chronologies.

For those rings for which the ring date did not match the ${ }^{14} \mathrm{C}$ date, we calculated the difference in years and compared these for each disc. In the supplementary information (S1) we provide a list of ring age, ${ }^{14} \mathrm{C}$ age and their difference for all sampled rings. If the difference in dating was constant across samples from one disc, the error in the ring counting occurred in the wood that was formed at a later date (thus, in direction to the bark). Still, in this case, the occurrence of consistent differences in age indicates that during the period covered by the sampled rings (between oldest and youngest rings) rings were formed annually. We found that this was the case for most of the discs and species (Fig. 6, S1). The maximum difference in dating was 9 years for Clarisia, 17 years for Peltogyne and $>40$ years for Cedrelinga. Large dating errors in ring analysis are probably associated with long periods of growth suppression, in which the growth in diameter is reduced such that ring recognition is not possible.
In the case of Cedrelinga, none of the ring dates was confirmed by ${ }^{14} \mathrm{C}$ dating (Fig. 6), but the consistent dating differences across samples within discs suggest annual ring formation. Based on the ${ }^{14} \mathrm{C}$ dating, ring boundary definition was improved, and tree-ring identification on three of the discs was corrected: in these samples, we initially identified false rings or we missed rings in the more recent wood. These corrected samples were used as a base to build the chronology. A fourth sample could not be corrected given the difficulty of ring recognition. The fifth sample had a $\mathrm{D}^{14} \mathrm{C}$ value much younger than expected (S1), which made it impossible to obtain a precise dating (data not shown in Fig. 6).

\section{Rainfall correlations}

Following verification of the annual character of the juvenile tree-rings, we proceeded with correlating chronologies with rainfall records. The correlation functions exhibited a different pattern among species. The chronology for Clarisia showed a significant negative correlation 
Fig. 2 Peltogyne cf. heterophylla. Transversal sections. a, c Juvenile tree, b, d Adult tree. Marginal parenchyma and small-diameter vessels can be used as ring boundary markers (a-d white arrows). Fibrous zones indicated by asterisks (*). Rings closer to pith can be discontinuous and wedging rings are common (c arrow heads). Resin/mucilage canals in juvenile and adult trees (d black arrows)
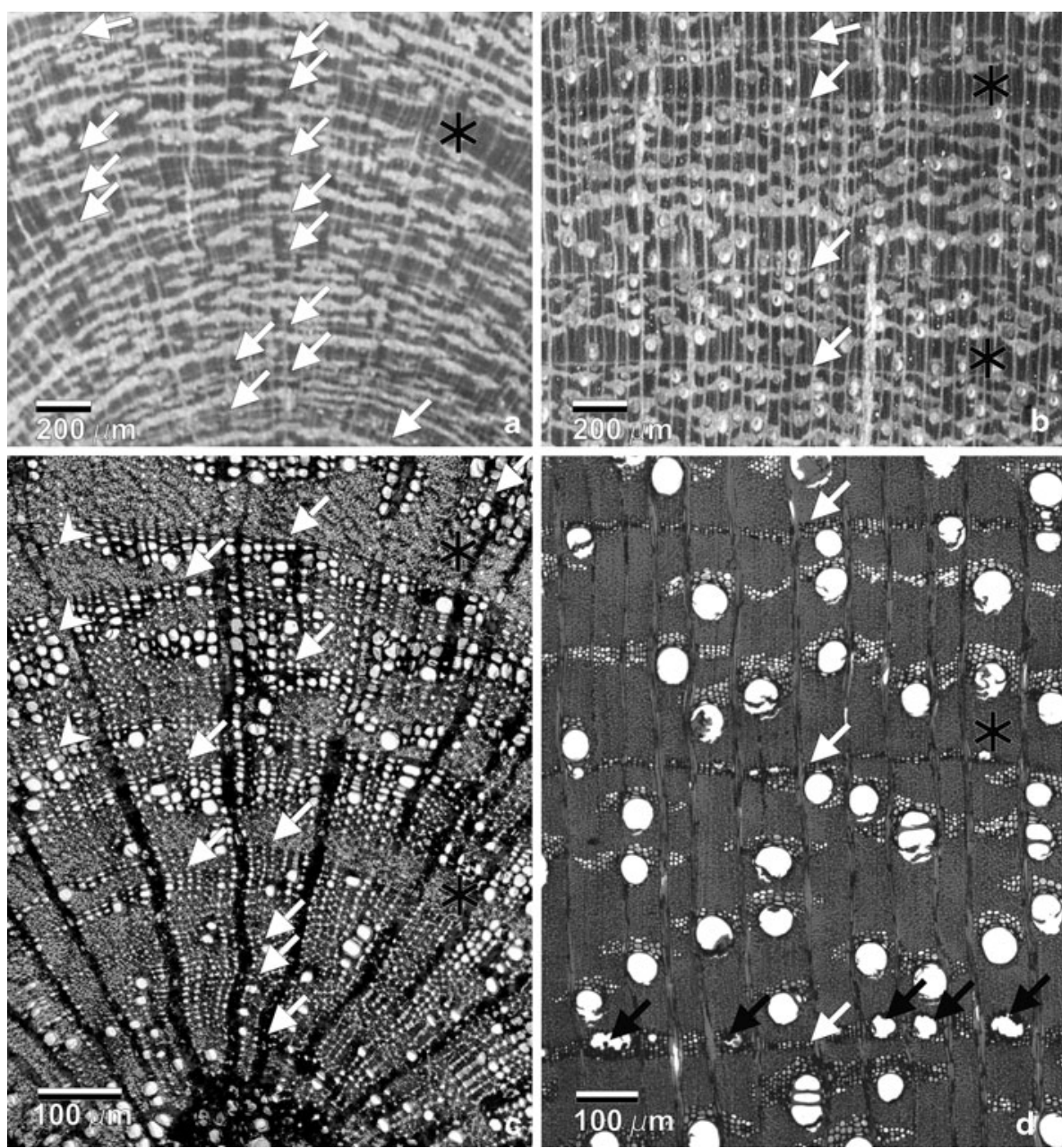

with precipitation in December, January and February of the current growing season. This negative correlation was also significant when we accounted for the total rainfall in the growing season (September-April) and the annual total precipitation (September-August, Fig. 7). The correlation for Peltogyne was positive $(P<0.05)$ with rainfall 1 year prior to the year of ring formation. Also, a general positive relation of ring width with rainfall during the previous year was found, but this was significant only for total dry-season rainfall and total annual rainfall (Fig. 7).

Surprisingly, the chronology of Cedrelinga showed a negative overall response to precipitation (Fig. 7). Wider rings in this species appeared to be associated with low wet-season rainfall during the current growing season or low total annual rainfall 2 years before ring formation (Fig. 7).

\section{Discussion}

Our results suggest that juvenile tree-rings of three Bolivian rainforest species are produced annually. In all cases, the annual character of the ring formation was verified by checking for synchronous growth patterns, ${ }^{14} \mathrm{C}$ bomb peak dating and correlations of ring width with rainfall.

Due to the ecological differences between the juvenile and adult trees of the studied species (Table 1), we expected variations in the anatomical ring characterization as suggested by some authors (Fukazawa 1984; Carlquist 2001). However, these differences were not distinct at ringboundary level. Probably, other variables such as vessel distribution, vessel number, vessel area (Heliñska-Raczkowska and Fabisiak 1999; Domec and Gartner 2003; Christensen-Dalsgaard et al. 2007) or measures of the axial parenchyma (Climent et al. 1998) can provide more information on variation in anatomy between juveniles and adults trees.

The ${ }^{14} \mathrm{C}$ dating proved to be a useful tool to verify the annual nature of the rings of Clarisia and Peltogyne. In the case of Cedrelinga, which presented more difficulties in the boundary definition, the use of ${ }^{14} \mathrm{C}$ allowed the correction of misidentified ring boundaries. Later, using the corrected samples as a basis, we built a chronology for this species. As the combination of methods has provided clarity on the 
Fig. 3 Cedrelinga

catenaeformis. Transversal sections. a, c Juvenile tree, b, d Adult tree. Growth ring markers characterized by thickwalled and radially flattened latewood fibres. a, b General aspect of the growth ring markers (arrows), $\mathbf{c}, \mathbf{d}$ details of the thick-walled latewood fibres of the growth rings (arrows). False rings indicated by stars
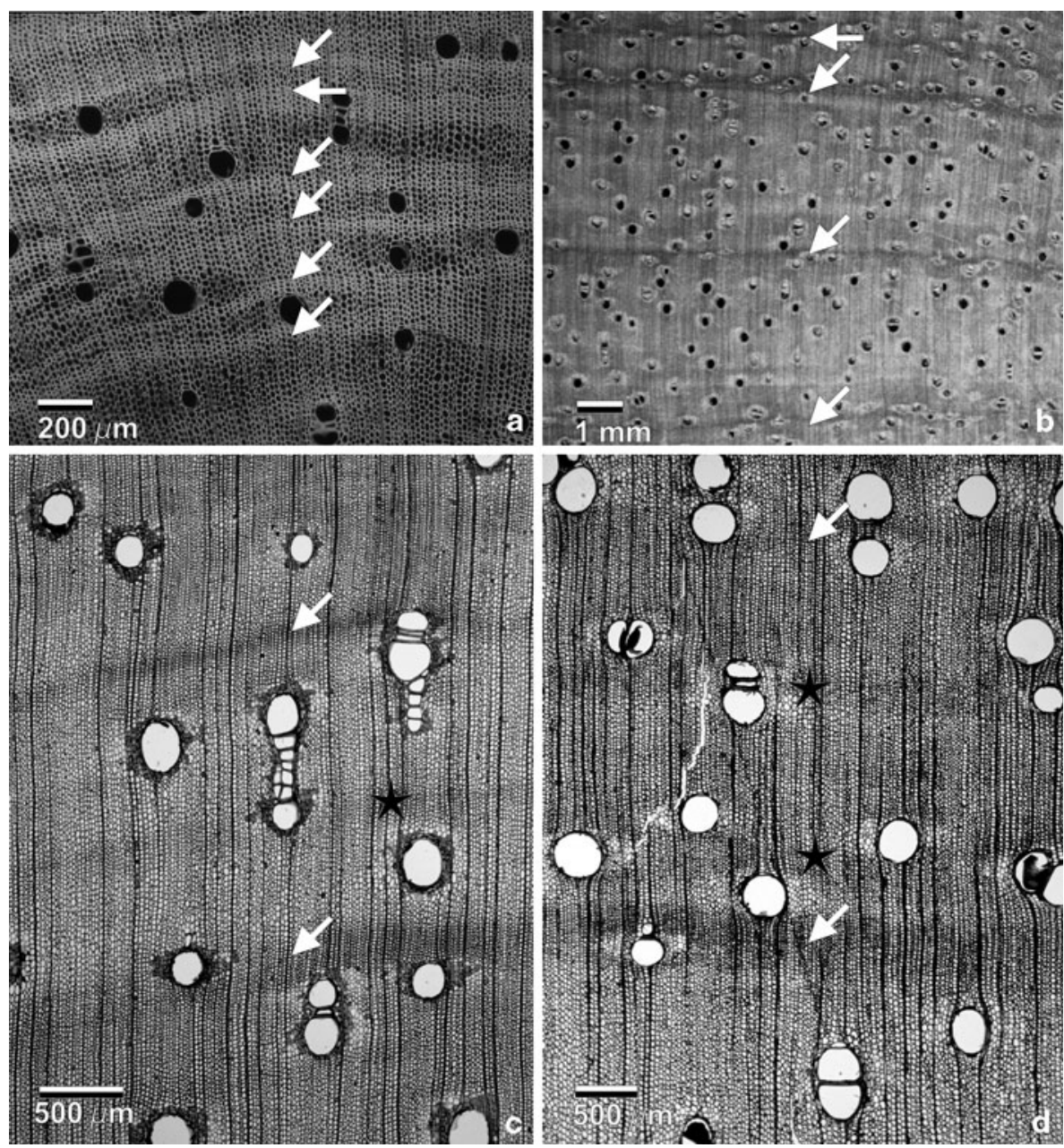

Table 2 Statistics of the tree-ring chronologies

\begin{tabular}{|c|c|c|c|c|c|c|c|c|c|c|c|}
\hline \multirow[t]{2}{*}{ Species } & \multirow{2}{*}{$\begin{array}{l}\text { Chronology } \\
\text { time span }\end{array}$} & \multirow{2}{*}{$\begin{array}{l}\text { Number of } \\
\text { trees (radii) }\end{array}$} & \multicolumn{2}{|c|}{ Tree-ring index } & \multirow{2}{*}{$\begin{array}{l}\text { Mean } \\
\text { sensitivity* }\end{array}$} & \multirow{2}{*}{$\begin{array}{l}\text { Serial } \\
\text { correlation* }\end{array}$} & \multicolumn{3}{|c|}{ Autoregresion order } & \multicolumn{2}{|l|}{ Rbar } \\
\hline & & & Mean & SD & & & $\mathrm{T}-1$ & $\mathrm{~T}-2$ & $\mathrm{~T}-3$ & Mean & $\mathrm{SD}$ \\
\hline Clarisia & 1837-2006 & $14(41)$ & 0.94 & 0.35 & 0.47 & 0.36 & 0.40 & 0.11 & - & 0.25 & 0.24 \\
\hline Peltogyne & 1840-2006 & $13(39)$ & 0.97 & 0.42 & 0.68 & 0.38 & 0.35 & 0.31 & -0.24 & 0.27 & 0.29 \\
\hline Cedrelinga & 1957-2006 & $12(38)$ & 1.00 & 0.28 & 0.47 & 0.37 & 0.23 & - & - & 0.21 & 0.04 \\
\hline
\end{tabular}

All data presented, by exception of those marked with asterisk (*) were extracted from the output of the program ARS41d_XP

* Data from COFECHA

annual character of ring formation in our study, we recommend conducting ${ }^{14} \mathrm{C}$ dating in early phases of tree-ring studies for species in which ring recognition is not straightforward or with a high frequency of wedging or false rings. As ${ }^{14} \mathrm{C}$ dating provides several probable year intervals (Hua and Barbetti 2004; Vieira et al. 2005), we advice to enhance the reliability of this method by taking at least three samples per tree.

The comparison of dates obtained by ring boundary analysis and those obtained by ${ }^{14} \mathrm{C}$ bomb peak dating may provide quantitative information about the accuracy of dating. A mean probability of ring misidentification for each species can be calculated, using the period of time under analysis and the number of misidentified rings. For Clarisia the mean probability to misidentify a ring was $9.9 \pm 9 \%$, i.e. there was a chance to add one false ring or to miss one true ring for every ten rings. For Peltogyne the mean misidentification probability was $12.9 \pm 17.1 \%$, so there is a chance to misidentify one ring for every ten rings. The highest difference in the dating was of 40 rings for a Cedrelinga tree; this sample was especially difficult. If we leave this sample out, the mean probability to misidentify a 

for juvenile trees of three Bolivian rainforest species. Note that the high temporal variation in the first years of Cedrelinga and Peltogyne chronologies was due to low sample size
Fig. 4 Standard chronologies

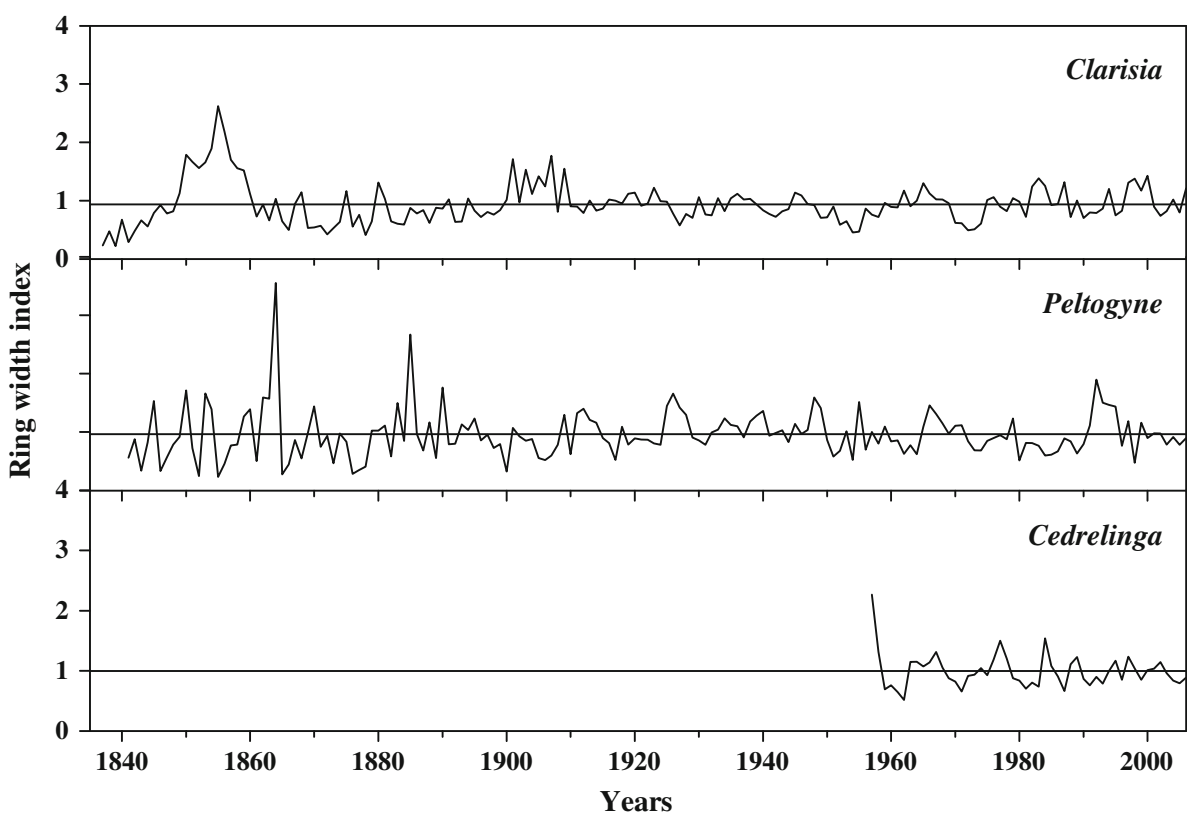

Fig. 5 Age versus diameter relations for juvenile trees of three Bolivian rainforest species. Only those samples used to build the chronologies are shown

Fig. 6 Relation between dates obtained from ring counts and from ${ }^{14} \mathrm{C}$ analysis for three Bolivian rainforest species. Points at the solid $y=x$ line are exact matches of ring and ${ }^{14} \mathrm{C}$ dates. Dotted lines link points belonging to the same tree
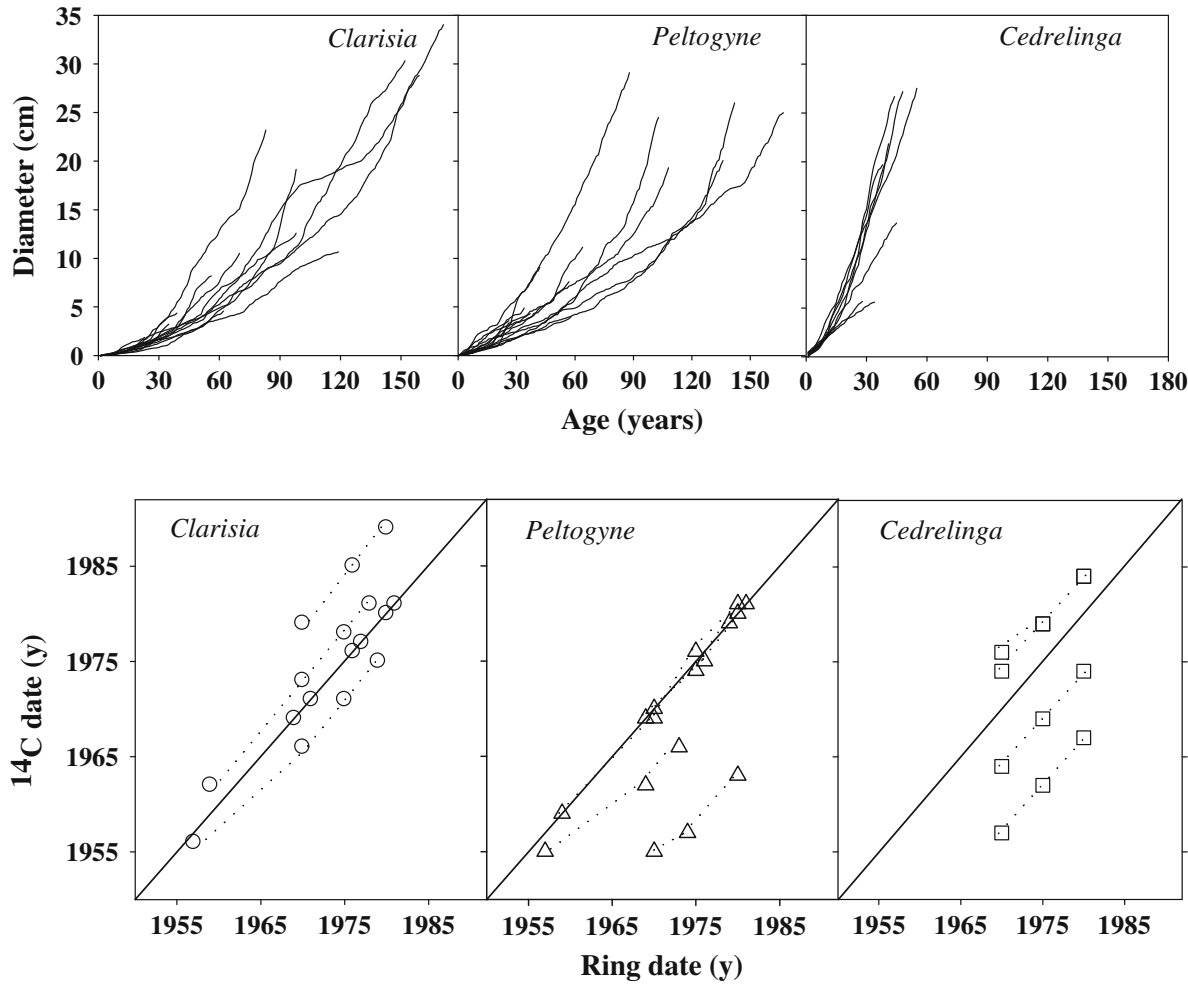

ring for Cedrelinga was $19.6 \pm 10.7 \%$ and thus two out of every ten rings. These errors in the dating can be corrected by crossdating among samples. However, due to the difficulty of the ring boundary recognition, some errors could be persistent and prevent the addition of more samples in the chronologies.

We were able to develop juvenile tree-ring chronologies for all the species of this study, using trees of variable age and diameter (Fig. 5). The low percentages of samples included in each chronology probably reflect the lack of strong common signal due to temporal variation in microsite conditions and perhaps, persistent dating problems. Despite these problems we show that trough tree-ring analysis we may obtain long-term data of juvenile growth in the tropics. Long-term juvenile data are valuable for the evaluation of important ecological hypotheses related to 
Fig. 7 Correlations of standard chronologies with the average monthly rainfall for juvenile trees of three Bolivian rainforest species. Rainfall of 35 consecutive months was used, as well as total rainfall during the growing season $(G S)$, dry season $(D S)$ and total annual precipitation for current growing year $(T-0)$, previous year $(T-1)$ and the year before that $(T-2)$. Correlation coefficients are significant $(P<0.05)$ if $>0.24$ for Clarisia and Peltogyne and $>0.27$ for Cedrelinga (stippled horizontal lines)

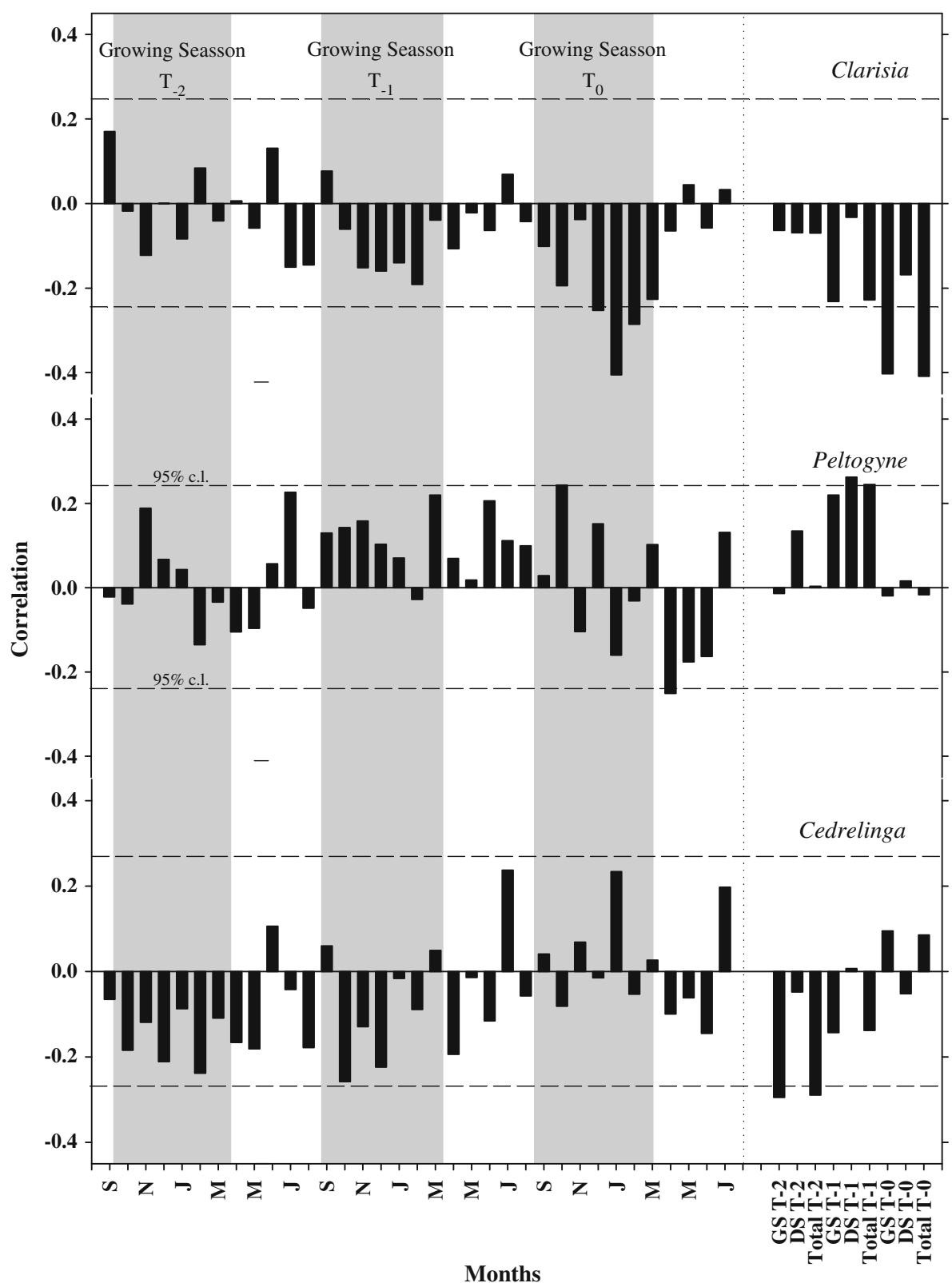

growth and survival of juvenile trees in the tropics (Rozendaal et al. 2010).

The ages of our juvenile trees ranged from 30 to 160,40 to 160 and 30 to 60 years for Clarisia, Peltogyne and Cedrelinga, respectively. The ages we report, for Clarisia and Peltogyne are in concordance with those reported by Vieira et al. (2005) and Brienen and Zuidema (2006b) for shade-tolerant individuals $<30 \mathrm{~cm}$ dbh. These studies showed that trees growing in the understory can have low growth rates over their entire life. In contrast, lightdependent trees present faster growth rates (Clark and Clark 1996; Vieira et al. 2005; Chambers et al. 1998; Brienen and Zuidema 2006b; Brienen et al. 2010) comparable to those reported for Cedrelinga in this study.
The majority of the tropical zones experience a dry season, or reduced precipitation for several months. Such seasonality is believed to produce clear rings by the induction of cambial dormancy (Worbes 1995, 2002; Carlquist 2001; Schongart et al. 2006). As a consequence, the ring width is expected to respond to rainfall (Carlquist 2001). Our three tree species presented different responses to rainfall, both in sign and in time (Fig. 7). Clarisia presented a negative correlation with the rainfall of the growing season. Peltogyne showed a positive correlation with the rainfall of the season prior to the ring formation, in contrast with the absence of correlations reported for the adult trees (Brienen and Zuidema 2005). Finally, Cedrelinga presented a negative correlation with the rainfall 
2 years before the growing season, which contrasts with reported positive correlation of the adult trees with the rainfall of the growing season (Brienen and Zuidema 2005). Complex reactions of juvenile trees to rainfall are likely if one takes into account that juveniles are evergreen trees and are growing in the low-light conditions of the forest understory (Worbes 1999). In addition, field and laboratory observations suggest different use of resources of our study species. Clarisia integrates silica in its structure, which may give it advantages against herbivores, as it increases wood toughness. Being a long-lived pioneer, Cedrelinga seems to invest mainly in height growth, at the expense of mechanical stability; for instance, we often observed juvenile trees of this species growing noticeably inclined. Finally, Peltogyne accumulates starch which could be mobilized to allow growth during periods of low resource availability. Worbes (1999) already discussed the occurrence and relevance of starch accumulation in tropical tree rings. In all, it is clear that such specific-species morphological and life-history attributes importantly determine responses to rainfall.

Our results show that rainfall may also be limiting growth in juvenile trees. The positive correlations between ring width and rainfall (Peltogyne), are comparable with other studies, (Stahle 1999; Worbes 1999; Brienen and Zuidema 2005; Schongart et al. 2006; Therrell et al. 2006; Solíz et al. 2009). Interestingly, negative correlations with rainfall were also observed (Cedrelinga and Clarisia). A negative correlation is difficult to interpret, but may be caused by the positive correlation of rainfall with cloudiness (Clark and Clark 1994; Lovejoy and Schertzer 2006), which results in lower solar radiation loads during highrainfall years. For light-limited juvenile trees in the forest understory, this may lead to negative growth-rainfall correlations.

Correlations between growth and rainfall 1 year prior to that of ring formation are not commonly found for tree species, but have been reported before for some tropical trees (Dünisch et al. 2003; Brienen and Zuidema 2005). For a tropical dry montane climate, Solíz et al. (2009) proposed that the sum of several years may be even a better predictor of growth. However, with our current knowledge on the factors determining diameter growth of the study species and on historical forest dynamics, the climate-growth relations that we report here will remain difficult to explain.

Acknowledgments We thank Edwin Rodriguez, Edmundo Pino, Nazareno Martinez, Miguel Cuadiay, Adhemar Saucedo, all the people who helped during the fieldwork and staff and personnel of PROMAB-UAB, for logistic support. Logging company 'MABET' for permission to work in their concessions and for logistic support. Special thanks to Antonio Carlos Franco Barbosa for his guidance and support during slides preparation. Feike Schieving and Marinus
Werger provided constructive comments on earlier versions of the manuscript.

Open Access This article is distributed under the terms of the Creative Commons Attribution Noncommercial License which permits any noncommercial use, distribution, and reproduction in any medium, provided the original author(s) and source are credited.

\section{References}

Alves ES, Angyalossy-Alfonso V (2000) Ecological trends in the wood anatomy of some brazilian species. 1. Growth rings and vessels. IAWA J 21:3-30

Baker PJ, Bunyavejchewin S, Oliver CD, Ashton PS (2005) Disturbance history and historical stand dynamics of a seasonal tropical forests in western Thailand. Ecol Monogr 75:317-343

Brienen R, Zuidema P (2005) Relating tree growth to rainfall in Bolivian rain forests: a test for six species using tree ring analysis. Oecologia 146:1-12

Brienen RJW, Zuidema PA (2006a) Lifetime growth patterns and ages of Bolivian rain forest trees obtained by tree ring analysis. J Ecol 94:481-493

Brienen RJW, Zuidema PA (2006b) The use of tree rings in tropical forest management: Projecting timber yields of four Bolivian tree species. For Ecol Manag 226:256-267

Brienen RJW, Zuidema PA, During HJ (2006) Autocorrelated growth of tropical forest trees: unraveling patterns and quantifying consequences. For Ecol Manag 237:179-190

Brienen RJW, Zuidema P, Martínez-Ramos M (2010) Attaining the canopy in dry and moist tropical forests: strong differences in tree growth trajectories reflect variation in growing conditions. Oecologia 163:485-496

Briffa KR (1995) Interpreting high-resolution proxy climate datathe example of dendroclimatology. In: von Storch H, Navarra A (eds) Analysis of climate variability, applications of statistical techniques. Springer, Berlin, pp 77-94

Carlquist SJ (2001) Comparative wood anatomy: systematic, ecological, and evolutionary aspects of dicotyledon wood, 2nd edn. Springer, Heidelberg

Chambers JQ, Higuchi N, Schimel JP (1998) Ancient trees in Amazonia. Nature 391:135-136

Christensen-Dalsgaard KK, Fournier M, Ennos AR, Barfod AS (2007) Changes in vessel anatomy in response to mechanical loading in six species of tropical trees. New Phytol 176:610-622

Clark DA, Clark DB (1994) Climate-induced annual variation in canopy tree growth in a Costa Rican tropical rain forest. J Ecol $82: 865-872$

Clark DB, Clark DA (1996) Abundance, growth and mortality of very large trees in neotropical lowland rain forest. For Ecol Manag 80:235-244

Climent J, Gil L, Pardos JA (1998) Xylem anatomical traits related to resinous heartwood formation in Pinus canariensis $\mathrm{Sm}$. Trees Struct Funct 12:139-145

Cook E (1985) A time series analysis approach to tree ring standardization. University of Arizona, Arizona

Cook ER, Holmes RL (1996) Guide for computer program ARSTAN. In: Grissino-Mayer HD, Holmes RL, Fritts HC (eds) The international tree-ring data bank program library version 2.0 user's manual. University of Arizona, Tucson, AZ, USA, pp 75-87

Cook ER, Kairiukstis LA (1990) Methods of dendrochronology: applications in the environmental sciences. Kluwer, Dordrecht 
Domec J-C, Gartner BL (2003) Relationship between growth rates and xylem hydraulic characteristics in young, mature and oldgrowth ponderosa pine trees. Plant Cell Environ 26:471-483

Dünisch O, Montoia VR, Bauch J (2003) Dendroecological investigations on Swietenia macrophylla King and Cedrela odorata L. (Meliaceae) in the central Amazon. Trees Struct Funct 17: 244-250

Fritts HC (1976) Tree rings and climate. Academic press, London

Fukazawa K (1984) Juvenile wood of hardwoods judged by density variation. IAWA Bull 5:65-73

Gerlach D (1984) Botanische Mikrotechnik. G. Thieme Verlag, Stuttgart, NY, $311 \mathrm{pp}$

Heliñska-Raczkowska L, Fabisiak E (1999) Radial variation of earlywood vessel lumen diameter as an indicator of the juvenile growth period in ash (Fraxinus excelsior L.). Eur J Wood Wood Prod 57:283-286

Holmes RL (1983) Computer-assisted quality control in tree-ring dating and measurement. Tree Ring Bull 43:69-78

Hua Q, Barbetti M (2004) Review of tropospheric bomb (super 14) C data for carbon cycle modeling and age calibration purposes. Radiocarbon 46:1273-1298

Lieberman D, Lieberman M (1987) Forest tree growth and dynamics at La Selva, Costa Rica (1969-1982). J Trop Ecol 3:347-358

Lovejoy S, Schertzer D (2006) Multifractals, cloud radiances and rain. J Hydrol 322:59-88

Martínez-Ramos M, Alvarez-Buylla ER (1998) How old are tropical rain forest trees? Trends Plant Sci 3:400-405

Mostacedo B, Justiniano J, Toledo M, Fredericksen T (2003) Guía dendrológica de especies forestales de Bolivia, 2nd edn. EL PAIS, Santa cruz, Bolivia

Navarro G, Maldonado M (2006) Geografia ecológica de Bolivia: Vegetacion y Ambientes Acuaticos, 4th edn. Centro de Ecologia Simon I. Patiño-Departamento de Difusión, Cochabamaba, Bolvia

Peacock J, Baker TR, Lewis SL, Lopez-Gonzalez G, Phillips OL (2007) The RAINFOR database: monitoring forest biomass and dynamics. J Veg Sci 18:535-542

Pinard MA, Putz FE, Rumíz D, Guzmán R, Jardim A (1999) Ecological characterization of tree species for guiding forest management decisions in seasonally dry forests in Lomerío, Bolivia. For Ecol Manag 113:201-213

Rozendaal DMA, Brienen RJW, Soliz-Gamboa CC, Zuidema PA (2010) Tropical tree rings reveal preferential survival of fast- growing juveniles and increased juvenile growth rates over time. New Phytol 185:759-769

Sass U, Killmann W, Eckstein D (1995) Wood formation in two species of dipterocarpaceae in Peninsular Malaysia. IAWA J 16:371-384

Schongart J, Orthmann B, Hennenberg KJ, Porembski S, Worbes M (2006) Climate-growth relationships of tropical tree species in West Africa and their potential for climate reconstruction. Glob Change Biol 12:1139-1150

Schulman E (1956) Dendroclimatic change in semiarid America. University of Arizona Press, Tucson, Arizona

Solíz C, Villalba R, Argollo J, Morales MS, Christie DA, Moya J, Pacajes J (2009) Spatio-temporal variations in Polylepis tarapacana radial growth across the Bolivian Altiplano during the 20th century. Palaeogeogr Palaeoclimatol Palaeoecol 281:296-308

Stahle DW (1999) Useful strategies for the development of tropical tree-ring chronologies. IAWA J 20:249-253

Swaine MD, Whitmore TC (1988) On the definition of ecological species groups in tropical rain forests. Plant Ecol 75:81-86

Therrell MD, Stahle DW, Ries LP, Shugart HH (2006) Tree-ring reconstructed rainfall variability in Zimbabwe. Clim Dyn 26:677-685

van der Borg K, Alderliesten C, Houston CM, de Jong AF, van Zwol NA (1987) Accelerator mass spectrometry with $14 \mathrm{C}$ and $10 \mathrm{Be}$ in utrecht. Nucl Instrum Methods Phys Res B 29:1943-1945

Vieira S, Trumbore S, Camargo PB, Selhorst D, Chambers JQ, Higuchi N, Martinelli LA (2005) Slow growth rates of Amazonian trees: consequences for carbon cycling. Proc Natl Acad Sci USA 102:18502-18507

Worbes M (1995) How to measure growth dynamics in tropical trees: a review. IAWA J 16:337-351

Worbes M (1999) Annual growth rings, rainfall-dependent growth and long-term growth patterns of tropical trees from the caparo forest reserve in Venezuela. J Ecol 87:391-403

Worbes M (2002) One hundred years of tree-ring research in the tropics-a brief history and an outlook to future challenges. Dendrochronologia 20:217-231

Worbes M, Junk WJ (1989) Dating tropical trees by means of ${ }^{14} \mathrm{C}$ from bomb tests. Ecology 70:503-507

Worbes M, Junk WJ (1999) How old are tropical trees? The persistence of a myth. IAWA J 20:255-260 